\begin{tabular}{|c|c|c|}
\hline B! & $\begin{array}{l}\text { BIODIK: Jurnal IImiah Pendidikan Biologi } \\
\text { ISSN 2580-0922 (online), ISSN 2460-2612 (print) } \\
\text { Volume 07, Nomor 04, Tahun 2021, Hal. 29-38 } \\
\text { Available online at: } \\
\text { https://online-journal.unja.ac.id/biodik }\end{array}$ & BIODIK \\
\hline
\end{tabular}

Research Article

open 2 Access

\title{
Studi Literatur: Pengaruh Penerapan Model Pembelajaran Kooperatif Tipe Make a Match Terhadap Kompetensi Belajar Peserta Didik
}

\section{(Literature Study: Effect of Applying Make a Match Type of Cooperative Learning on Students Learning Competencies)}

Wirda Taufik*, Helendra, Syamsurizal, dan Heffi Alberida

Program Studi Pendidikan Biologi,

Fakultas Matematika dan IImu Pengetahuan Alam, Universitas Negeri Padang

Jalan Prof. Dr. Hamka Air Tawar Barat, Padang Utara, Kota Padang, Sumatera Barat

${ }^{*}$ Corresponding authors: wirdataufik98@gmail.com

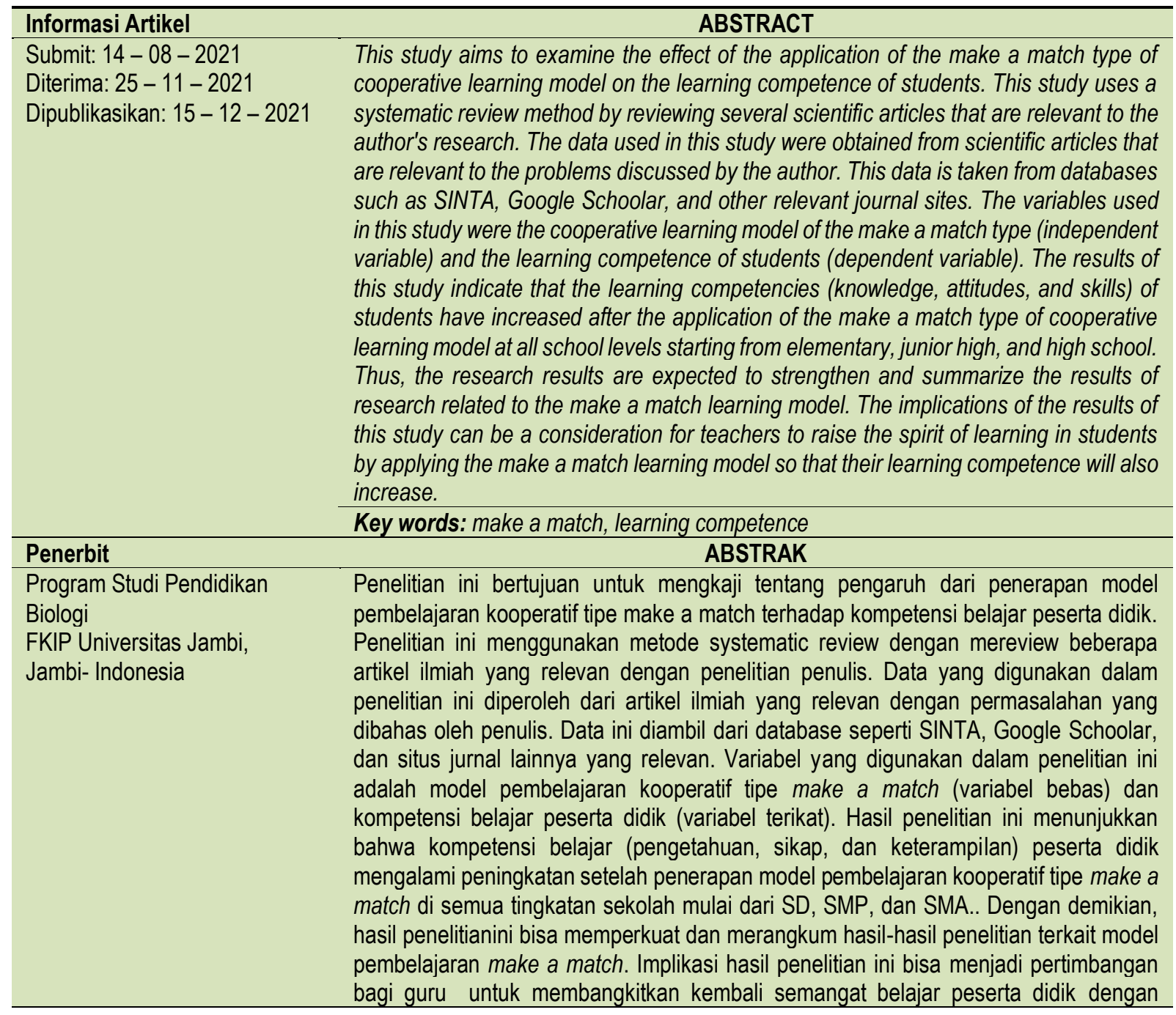




\section{PENDAHULUAN}

Menurut Undang-Undang No. 20 Tahun 2003 pendidikan merupakan suatu upaya yang dilakukan dalam proses pembelajaran untuk membantu individu dalam mengembangkan kecerdasan dan potensi yang dimilikinya. Pendidikan ini bukanlah hanya program semata, tetapi pendidikan ini memiliki tujuan yang harus dicapai. Untuk mencapai tujuan pendidikan ini maka pemerintah Indonesia terus berusaha meningkatkan mutu pendidikan. Salah satu upaya untuk meningkatkan mutu pendidikan adalah dengan melaksanakan pembaharuan terhadap komponen-komponen pendidikan, diantaranya adalah kurikulum.

Kurikulum ini berfungsi sebagai pedoman untuk melaksanakan proses pembelajaran di sekolah (Sudjana, 2011). Proses pembelajaran adalah interaksi antara peserta didik dengan lingkungan sekitarnya untuk memperoleh pengetahuan, keterampilan, dan sikap. Adapun proses pembelajaran dalam konteks kurikulum 2013 yakni menekankan pada proses pembelajaran yang autentik, menantang dan bermakna bagi peserta didik. Hal ini berarti kurikulum 2013 lebih menuntut peserta didik untuk berperan secara aktif dalam proses pembelajaran di kelas (student centered learning).

Berdasarkan hasil wawancara penulis dengan guru mata pelajaran biologi di salah satu SMA di Kota Padang diketahui bahwa masih terdapat kekurangan dalam proses pembelajaran biologi diantaranya yakni masih rendahnya minat peserta didik dalam pembelajaran biologi dan proses pembelajaran biologi masih didominasi oleh guru (teacher centered learning) meskipun guru telah menerapkan beberapa model pembelajaran yang memicu peserta didik untuk terlibat aktif, di antaranya dengan menerapkan model pembelajaran langsung, numbered head together, discovery learning dan studi lapangan. Akan tetapi, pada kenyataannya di lapangan guru lebih cenderung menggunakan model pembelajaran konvensional (metode diskusi dan ceramah). Hal ini menyebabkan pembelajaran menjadi kurang menarik sehingga membuat peserta didik menjadi bosan, jenuh, kurang aktif dan merasa malas untuk belajar. Hal ini menyebabkan banyak peserta didik yang kurang fokus mendengarkan dan beberapa peserta didik masih ada yang justru melakukan kesibukan lain.

Pernyataan ini diperkuat oleh hasil observasi peneliti melalui penyebaran angket terhadap 72 orang peserta didik diperoleh bahwa 54 orang peserta didik atau $75 \%$ peserta didik kurang fokus dalam pembelajaran biologi, 58 orang atau $80,5 \%$ peserta didik merasa bosan dengan cara guru dalam mmemberikan materi pelajaran (model pembelajaran yang diterapkan), dan metode diskusi yang diterapkan juga tidak berjalan optimal. Hal ini diamati langsung oleh peneliti sewaktu Praktek Lapangan Kependidikan bahwa ketika melaksanakan diskusi hanya beberapa peserta didik yang berpartisipasi dalam kelompoknya. Dengan demikian, dapat diketahui bahwa kerja sama antar peserta didik masih tergolong rendah.

Kebosanan dan kejenuhan peserta didik menyebabkan peserta didik tidak tertarik dengan metode ceramah dan diskusi yang sudah sering dilaksanakan sehingga peserta didik bermalas-malasan ketika diminta berdiskusi. Akibatnya permasalahan ini berdampak terhadap sikap peserta didik, terutama sikap kerja sama dalam berdiskusi, bahkan hal ini menyebabkan kompetensi pengetahuan peserta didik 
menjadi rendah. Hal ini dapat dilihat dari hasil kompetensi pengetahuan peserta didik kelas XI yang penulis paparkan pada tabel 1 di bawah ini.

Tabel 1. Rata-rata Hasil Ujian Tengah Semester (UTS) Kelas XI MIPA

\begin{tabular}{ccc}
\hline Kelas & $\begin{array}{c}\text { Jumlah Peserta } \\
\text { Didik }\end{array}$ & Rata-rata Nilai UTS \\
\hline XI MIPA 1 & 36 & 63,37 \\
\hline XI MIPA 2 & 36 & 56,20 \\
\hline XI MIPA 3 & 36 & 54,07 \\
\hline XI MIPA 4 & 36 & 37,83 \\
\hline XI MIPA 5 & 36 & 51,18 \\
\hline XI MIPA 6 & 36 & 42,72 \\
\hline *Sumber: Guru Mata Pelajaran Biologi Salah Satu SMA di Kota Padang
\end{tabular}

Berdasarkan rata-rata hasil ujian tengah semester di atas dapat diketahui bahwa kompetensi pengetahuan peserta didik masih tergolong rendah. Hal ini dilihat dari rata-rata tersebut bahwa nilai peserta didik tidak mencapai kriteria ketuntasan minimal (KKM) yang diharapkan. Dampak lainnya dari rendahnya kompetensi pengetahuan ini juga mempengaruhi kompetensi sikap peserta didik seperti yang sudah dipaparkan sebelumnya, serta juga berdampak terhadap keterampilan peserta didik. Faktanya, selama kegiatan PPLK peneliti mengamati bahwa kegiatan praktikum masih belum berjalan dengan optimal yakni masih banyak peserta didik yang bermain-main ketika praktikum berlangsung. Selain itu hal ini juga terlihat ketika peserta didik diminta membuat video dalam setiap praktikum, hanya sekitar $60 \%$ tiap kelasnya yang mengerjakan dan mengumpulkan video tersebut. Dengan demikian guru harus mampu untuk membangkitkan keinginan dan minat peserta didik untuk mengembangkan ketiga kompetensi belajar tersebut (pengetahuan, sikap, dan keterampilan).

Adapun salah satu upaya untuk meningkatkan sikap kerja sama, hasil belajar (kompetensi pengetahuan), dan keterampilan peserta didik yaitu dengan menerapkan model pembelajaran. Menurut kajian literatur model pembelajaran yang dapat meningkatkan sikap kerja sama adalah model pembelajaran kooperatif. Hal ini sejalan dengan pendapat Asma (2012: 2-3) model pembelajaran kooperatif merupakan pembelajaran yang menekankan kerja sama antar peserta didik dalam belajar kelompok dan melatih peserta didik untuk bertanggung jawab terhadap aktivitas belajar kelompoknya, sehingga semua anggota kelompok dapat menguasai materi yang dipelajari dengan baik.

Setelah mengkaji dan juga melaksanakan observasi di lapangan dengan penggunaan angket, peneliti menemukan sebuah model pembelajaran kooperatif yang dianggap cocok untuk mengatasi permasalahan di atas yakni model pembelajaran kooperatif tipe make a match. Menurut Lorna Curran (dalam Rusman, 2011: 223) model pembelajaran ini memiliki keunggulan dalam memberikan suasana belajar yang menyenangkan karena adanya pembelajaran yang dipadukan dengan permainan (mencocokkan kartu). Penerapan model pembalajaran kooperatif tipe make a match ini memiliki beberapa sintaks atau langkah-langkah yaitu (1) menyampaikan materi atau memberi tugas kepada siswa untuk mempelajari materi, (2) membagi siswa ke dalam 2 kelompok, misalnya kelompok $A$ dan kelompok $B$. Kedua kelompok diminta untuk saling berhadapan, (3) membagikan kartu pertanyaan kepada kelompok A dan kartu jawaban kepada kelompok B, (4) menyampaikan kepada siswa bahwa mereka harus mencari/mencocokkan kartu yang dipegang dengan kartu kelompok lain dalam batas waktu yang sudah ditentukan, (5) meminta semua kelompok A untuk mencari pasangan dari kartunya di kelompok B dan jika sudah menemukan pasangannya mereka harus melaporkan diri kepada guru untuk dicatat, (6) Jika waktu sudah habis, maka guru harus memberitahukannya dan siswa yang belum menemukan 
pasangannya diminta untuk berkumpul tersendiri, (7) memanggil beberapa pasangan untuk presentasi, (8) memberikan konfirmasi tentang kebenaran dan kecocokan pertanyaan dan jawaban dari pasangan yang memberikan presentasi, dan (9) membuat kesimpulan terhadap materi yang sudah dipelajari (Huda, 2014).

Dengan demikian, pembelajaran kooperatif tipe make a match ini menekankan peserta didik untuk berdiskusi secara berpasangan sehingga dapat mengurangi kelemahan pembelajaran kooperatif yang biasanya didominasi oleh peserta didik yang pintar. Dampak penerapan pembelajaran kooperatif tipe make a match ini diharapkan akan membuat peserta didik merasa semangat dan lebih fokus dalam belajar sehingga semua kompetensi belajar dapat tercapai.

\section{METODE PENELITIAN}

Jenis penelitian ini adalah penelitian kuantitatif dengan menggunakan metode studi literatur (systematic review). Systematic review merupakan suatu metode untuk melakukan identifikasi, evaluasi, dan interprestasi terhadap beberapa hasil penelitian dari jurnal-jurnal ilmiah, teori-teori dan temuantemuan orang lain yang relevan. Penelitian ini dilaksanakan pada bulan Oktober 2019 hingga Juni 2020. Observasi penelitian dilaksanakan pada oktober dan pada bulan juni 2020 melaksanakan review artikel.

Sumber data dalam penelitian ini yaitu jurnal-jurnal ilmiah yang terdapat pada database seperti SINTA, Google Shoolar, dan situs jurnal lainnya yang relevan. Adapun populasi dan sampel yang digunakan dalam penelitian ini adalah jurnal yang bersumber setidaknya dari lima jurnal ilmiah yang terakreditasi SINTA dan jurnal lainnya yang relevan. Sedangkan prosedur penelitiannya terdiri dari beberapa tahapan yaitu menentukan pertanyaan penelitian, mencari literatur yang sesuai dengan pertanyaan penelitian, mengumpulan jurnal ilmiah atau literatur-literatur yang relevan, melaksanakan review artikel jurnal-jurnal ilmiah yang sudah ditemukan, melakukan analisis jurnal menggunakan teknik reduksi data, penyajian data, dan verifikasi data, lalu membuat kesimpulan dari review artikel yang telah dilaksanakan.

\section{HASIL PENELITIAN DAN PEMBAHASAN}

Model pembelajaran kooperatif tipe make a match merupakan pembelajaran yang berorientasi pada peserta didik (student center), yakni melakukan pembelajaran dengan bantuan media kertu soal dan jawaban sehingga dapat meningkatkan semangat belajar peserta didik. Hal ini juga akan berdampak terhadap meningkatnya kompetensi pengetahuan, sikap kerja sama, dan keterampilan peserta didik. Data yang digunakan dalam penelitian ini berupa datas ekunder yang dianalisis dan berkaitan dengan variabel penelitian dan didapatkan 12 artikel yang masuk dalam kategori penyajian data dapat dilihat pada table 2.

Tabel 2. Hasil Reduksi Data

\begin{tabular}{cllccc}
\hline $\begin{array}{c}\text { Kode } \\
\text { Artikel }\end{array}$ & \multicolumn{1}{c}{ Penulis } & \multicolumn{1}{c}{ Judul Artikel } & $\begin{array}{c}\text { Metode } \\
\text { Penelitian }\end{array}$ & $\begin{array}{c}\text { Data yang } \\
\text { digunakan }\end{array}$ & $\begin{array}{c}\text { Data yang } \\
\text { direduksi }\end{array}$ \\
\hline M1 & $\begin{array}{l}\text { Makmur } \\
\text { Sirait, dkk, }\end{array}$ & $\begin{array}{l}\text { Pengaruh Model Pembelajaran } \\
\text { Kooperatif Tipe Make a Match }\end{array}$ & Eksperimen & $\begin{array}{c}\text { Kompetensi } \\
\text { pengetahuan }\end{array}$ & - \\
& $(2013$, S5) & Terhadap Hasil Belajar Siswa & & & \\
\hline M2 & Nurhamid & Pengaruh Model Pembelajaran & Kuantitatif & Kompetensi & Motivasi dan \\
& $(2018$, S4) & Kooperatif Tipe Make a Match & dengan Teknik & pengetahuan & kreativitas \\
& & Terhadap Kreativitas, Motivasi, dan & Pengambilan & & dalam belajar \\
& & Hasil Belajar Biologi pada Materi & Data berupa & & \\
& & & Tes dan Angket & & \\
& & & & &
\end{tabular}




\begin{tabular}{|c|c|c|c|c|c|}
\hline $\begin{array}{l}\text { Kode } \\
\text { Artikel }\end{array}$ & Penulis & Judul Artikel & $\begin{array}{c}\text { Metode } \\
\text { Penelitian }\end{array}$ & $\begin{array}{l}\text { Data yang } \\
\text { digunakan }\end{array}$ & $\begin{array}{l}\text { Data yang } \\
\text { direduksi }\end{array}$ \\
\hline & & $\begin{array}{l}\text { Tumbuhan Lumut Kelas X SMA } \\
\text { Negeri } 2 \text { Sarmi }\end{array}$ & & & \\
\hline M3 & $\begin{array}{l}\text { Khoirunnisa, } \\
\text { dkk (2016) }\end{array}$ & $\begin{array}{l}\text { Efektivitas Model Make a Match } \\
\text { Terhadap Hasil Belajar Siswa Materi } \\
\text { Archaebacteria dan Eubacteria di } \\
\text { SMA }\end{array}$ & $\begin{array}{l}\text { Quasi } \\
\text { Experimental } \\
\text { Design }\end{array}$ & $\begin{array}{l}\text { Kompetensi } \\
\text { pengetahuan }\end{array}$ & - \\
\hline M4 & $\begin{array}{l}\text { Marthinus } \\
\text { Kayame, dkk, } \\
(2014, \text { S4) }\end{array}$ & $\begin{array}{l}\text { Pengaruh Pembelajaran Kooperatif } \\
\text { Tipe Make a Match dan Hasil Belajar } \\
\text { Terhadap Motivasi Belajar } \\
\text { Matematika Peserta Didik Kelas XI } \\
\text { IPA SMA YPPGI Wamena Kabupaten } \\
\text { Jaya Wijaya }\end{array}$ & Ex-post Facto & $\begin{array}{l}\text { Kompetensi } \\
\text { pengetahuan }\end{array}$ & $\begin{array}{l}\text { Motivasi } \\
\text { belajar }\end{array}$ \\
\hline M5 & $\begin{array}{l}\text { Rilda Weni } \\
(2017, \text { S2) }\end{array}$ & $\begin{array}{l}\text { Model Cooperative Learning Tipe } \\
\text { Make a Match untuk Meningkatkan } \\
\text { Hasil Belajar dan Aktivitas Siswa }\end{array}$ & $\begin{array}{c}\text { Penelitian } \\
\text { Tindakan Kelas }\end{array}$ & $\begin{array}{l}\text { Kompetensi } \\
\text { pengetahuan }\end{array}$ & Aktivitas siswa \\
\hline M6 & $\begin{array}{l}\text { Rina Suryati } \\
\text { Nurhidayah, } \\
\text { dkk (S5, } \\
\text { 2017) }\end{array}$ & $\begin{array}{l}\text { Penerapan Model Pembelajaran } \\
\text { Kooperatif Tipe Make a Match untuk } \\
\text { Meningkatkan Hasil Belajar Siswa } \\
\text { pada Materi Keragaman Suku Bangsa } \\
\text { dan Budaya }\end{array}$ & $\begin{array}{c}\text { Penelitian } \\
\text { Tindakan Kelas } \\
\text { (PTK) }\end{array}$ & $\begin{array}{l}\text { Kompetensi } \\
\text { pengetahuan }\end{array}$ & - \\
\hline M7 & $\begin{array}{l}\text { Sabrianto, } \\
\text { dkk (2013, } \\
\text { S3) }\end{array}$ & $\begin{array}{l}\text { Upaya Meningkatkan Hasil Belajar } \\
\text { Fisika Melalui Penerapan Model } \\
\text { Pembelajaran Kooperatif Tipe Make a } \\
\text { Match Pada Siswa Kelas X XKJ SMK } \\
\text { Nasional Makassar }\end{array}$ & $\begin{array}{c}\text { Penelitian } \\
\text { Tindakan Kelas }\end{array}$ & $\begin{array}{l}\text { Kompetensi } \\
\text { pengetahuan }\end{array}$ & - \\
\hline M8 & $\begin{array}{l}\text { Debby } \\
\text { Verama Sari, } \\
\text { dkk (2018, } \\
\text { S4) }\end{array}$ & $\begin{array}{l}\text { Keefektifan Kartu Make a Match pada } \\
\text { Materi Sistem Rangka Terhadap Hasil } \\
\text { Belajar Siswa Kelas XI SMA }\end{array}$ & $\begin{array}{l}\text { Mengggunakan } \\
\text { model ASSURE }\end{array}$ & $\begin{array}{l}\text { Kompetensi } \\
\text { sikap }\end{array}$ & $\begin{array}{l}\text { Kompetensi } \\
\text { pengetahuan } \\
\text { dan } \\
\text { keterampilan }\end{array}$ \\
\hline M9 & $\begin{array}{l}\text { Irma } \\
\text { Paramita, dkk } \\
(2012, \text { S3) }\end{array}$ & $\begin{array}{l}\text { Penggunaan Model Cooperative } \\
\text { Learning Type Make a Match } \\
\text { Terhadap Hasil Belajar Sistem Gerak }\end{array}$ & $\begin{array}{c}\text { Quasi } \\
\text { Experiment }\end{array}$ & $\begin{array}{l}\text { Kompetensi } \\
\text { sikap }\end{array}$ & $\begin{array}{l}\text { Kompetensi } \\
\text { pengetahuan } \\
\text { dan } \\
\text { keterampilan } \\
\end{array}$ \\
\hline M10 & $\begin{array}{l}\text { Apriyani, dkk } \\
(\mathrm{S} 1,2016)\end{array}$ & $\begin{array}{l}\text { Pengaruh Model Cooperative } \\
\text { Learning Tipe Make a Match dalam } \\
\text { Pembelajaran IPA Terhadap } \\
\text { Keterampilan Sosial dan Hasil Belajar } \\
\text { Kognitif Siswa SMP }\end{array}$ & $\begin{array}{c}\text { Quasi } \\
\text { Experiment }\end{array}$ & $\begin{array}{l}\text { Kompetensi } \\
\text { sikap }\end{array}$ & $\begin{array}{l}\text { Kompetensi } \\
\text { pengetahuan }\end{array}$ \\
\hline M11 & $\begin{array}{l}\text { Nurdiani, dkk } \\
(2019, \text { S5) }\end{array}$ & $\begin{array}{l}\text { Pengaruh Pemberian Sistem Point } \\
\text { pada Model Pembelajaran Make a } \\
\text { Match Terhadap Kompetensi Belajar } \\
\text { IPA Peserta Didik Kelas VIII SMPN } 21 \\
\text { Padang }\end{array}$ & Eksperimen & $\begin{array}{l}\text { Kompetensi } \\
\text { keterampilan }\end{array}$ & $\begin{array}{l}\text { Kompetensi } \\
\text { pengetahuan } \\
\text { dan sikap }\end{array}$ \\
\hline M12 & $\begin{array}{l}\text { Meidina } \\
\text { Fadilla, dkk } \\
(2019, \text { S5) }\end{array}$ & $\begin{array}{l}\text { Pengaruh Penerapan Model } \\
\text { Pembelajaran Kooperatif Tipe Make a } \\
\text { Match Terhadap Kompetensi Belajar } \\
\text { Peserta Didik di SMPN } 1 \text { Solok }\end{array}$ & Eksperimen & $\begin{array}{l}\text { Kompetensi } \\
\text { keterampilan }\end{array}$ & $\begin{array}{l}\text { Kompetensi } \\
\text { pengetahuan } \\
\text { dan sikap }\end{array}$ \\
\hline
\end{tabular}

Berdasarkan artikel-artikel terkait, diperoleh data berupa nilai rata-rata kelas eksperimen dan kelas kontrol (nilai rata-rata pretest dan posttest). Hasil rekapitulasi data yang diperoleh dari artikel yang dianalisis dapat kita lihat pada tabel 3 .

Tabel 3. Rekapitulasi Sampel Data Hasil Penelitian Artikel yang dianalisis 


\begin{tabular}{ccccc}
\hline $\begin{array}{c}\text { Kode } \\
\text { Artikel }\end{array}$ & $\begin{array}{c}\text { Aspek yang } \\
\text { dilihat }\end{array}$ & $\begin{array}{c}\text { Nilai Rata-rata } \\
\text { Posttest Kelas Kontrol }\end{array}$ & $\begin{array}{c}\text { Nilai Rata-rata } \\
\text { Posttest Kelas } \\
\text { Eksperimen }\end{array}$ & Keterangan \\
\hline M1 & Pengetahuan & 62 & 70,17 & - \\
\hline M2 & Pengetahuan & - & 72,19 & - \\
\hline M3 & Pengetahuan & 13,90 & 15,40 & Dari deskripsi hasil \\
\hline M4 & Pengetahuan & - & - & - \\
\hline M5 & Pengetahuan & 60 & 76,88 & Dilihat per siklus \\
\hline M6 & Pengetahuan & - & - & - \\
\hline M7 & Pengetahuan & 66,18 & 71,03 & Dilihat dari persentase hasil penilaiannya \\
\hline M8 & Sikap & - & - & Dilihat dari persentase hasil penilaiannya \\
\hline M9 & Sikap & - & - & - \\
\hline M10 & Sikap & 76,33 & 80,42 & - \\
\hline M11 & Keterampilan & 78,21 & 84,71 & - \\
\hline M12 & Keterampilan & 72,00 & 83,21 & \\
\hline
\end{tabular}

Berdasarkan hasil kajian studi literatur pada beberapa artikel yang relevan dengan penerapan model pembelajaran kooperatif tipe make a match, penulis memperoleh bahwa sebagian besar penerapan model pembelajaran make a match terhadap kompetensi belajar peserta didik memberikan pengaruh yang positif mulai dari sekolah dasar (SD), Sekolah Menengah Pertama (SMP), Sekolah Menengah Atas (SMA), dan Sekolah Menengah Kejuruan (SMK). Model pembelajaran koperatif tipe make a match ini merupakan model pembelajaran dengan teknik mencari pasangan dimana peserta didik akan diminta mencari pasangan dari kartu soal dan jawaban sambil belajar mengenai suatu konsep dalam suasana yang menyenangkan (Yunus, 2018).

Berdasarkan hasil artikel yang sudah dianalisis, diketahui bahwa model pembelajaran kooperatif tipe make a match dapat meningkatkan kompetensi sikap, pengetahuan, dan keterampilan peserta didik. Kompetensi sikap dibahas pada artikel M8, M9, dan M10, kompetensi keterampilan dibahas dalam artikel M11 dan M12, kompetensi pengetahuan dibahas dalam M1, M2, M3, M4, M5, M6, dan M7.

. Kompetensi pengetahuan merupakan salah satu kompetensi yang paling sering digunakan sebagai alat untuk mengukur kemampuan seseorang, padahal faktanya seseorang yang memiliki kompetensi pengetahuan tinggi terkadang belum tentu memiliki kompetensi sikap ataupun keterampilan yang baik. Kompetensi pengetahuan merupakan kemampuan intelektual yang harus dipelajari dan dimiliki oleh setiap peserta didik sesuai dengan tuntutan kurikulum yang ada.Kompetensi pengetahuan ini dapat diukur dengan menggunakan tes hasil belajar.Melalui hasil tes inilah kita dapat mengukur sejauh mana pengetahuan atau kemampuan kognitif yang telah dimiliki oleh peserta didik.

Berdasarkan hasil analisis artikel M1 menunjukkan bahwa model pembelajaran kooperatif tipe make a match ini memberikan hasil yang positif terhadap kompetensi belajar peserta didik. Faktanya hasil posttest peserta didik pada kelas eksperimen lebih tinggi dibandingkan kelas control (eskperimen 70,17 dan control 62). Hal ini disebabkan karena pada model ini suasana pembelajaran lebih menyenangkan sehingga minat peserta didik menjadi lebih tinggi dalam proses belajar. Selain itu, dalam pembelajaran peserta didik menjadi semakin aktif sehingga bias mencapi tujuan pembelajaran dengan baik.

Keberhasilan model pembelajaran kooperatif tipe make a match ini dalam meningkatkan hasil belajar peserta didik juga didukung oleh penelitian M2 yakni diketahui hasil rata-rata n-Gain pada pada pretest dan posttest tumbuhan lumut, diperoleh skor pretes 43,83 dan posttest 72,19 . Sehingga $n$-Gain sebesar 0,5000 berada pada kategori sedang. Dengan demikian, diketahui bahwa terdapat peningkatan yang signifikan terhadap hasil belajar biologi peserta didik pada materi tumbuhan lumut. 
Selain itu, keberhasilan model pembelajaran kooperatif tipe make a match dalam pembelajaran biologi juga juga dibuktiken oleh penelitian M3 yakni model pembelajaran make a match ini dapat meningkatkan hasil belajar peserta didik pada materi Archaebacteria dan Eubacteria di SMA. Hal ini dapat dilihat dari hasil persentase ketuntasan hasil belajar peserta didik yakni kelas yang menerapkan model pembelajaran make a match memiliki persentase lebih tinggi dibandingkan dengan kelas yang tidak menerapkannya.

Penelitian selanjutnya yang juga mendukung adanya pengaruh model pembelajaran make a match terhadap kompetensi belajar peserta didik dibuktikan oleh penelitian M4 dengan nilai rata-rata kompetensi pengetahuan kelas dengan model pembelajaran kooperatif tipe make a match ini lebih tinggi yakni sebesar 84,21 , sedangkan kelas kontrolnya 76,81 . Hasil penelitian lainnya yang juga mendukung penelitian di atas yakni penelitian M7 yang menyatakan bahwa model pembelajaran make a match ini dapat meningkatkan hasil belajar peserta didik kelas X SMK pada mata pelajaran fisika. Penelitian tindakan kelas ini juga membuktikan keberhasilan model pembelajaran kooperatif tipe make a match yakni adanya peningkatan nilai siswa dari setiap pertemuan pembelajaran yang telah dilaksanakan.

Tidak hanya di tingkat SMP dan SMA/SMK, model pembelajaran kooperatif tipe make a match ini juga memberikan pengaruh yang positif terhadap proses pembelajaran di tingkat sekolah dasar. Hal ini dibuktikan oleh beberapa hasil penelitian yang dimuat dalam beberapa jurnal ilmiah. Salah satu penelitian yang membuktikannya yakni penelitian M5 yang dimuat dalam jurnal Penelitian Pendidikan Indonesia. Dalam penelitian ini, peneliti melaksanakan penelitian di SDN 21 Batang Anai melalui dua siklus. Melalui penelitian ini, peneliti memperoleh bahwa persentase ketuntasan kelas terus meningkat secara signifikan di setiap siklus. Hal ini juga sejalan dengan hasil penelitian M6 di SDN 12 Sindang II, Sumedang Utara. Penelitian ini membuktikan adanya peningkatan kompetensi pengetahuan peserta ddiik di setaip siklus baik dari siklus satu hingga tiga.

Analisis dari beberapa artikel di atas semakin memperkuat fakta di lapanagan bahwa model pembelajaran kooperatif tipe make a match ini dapat meningkatkan hasil belajar peserta didik. Peningkatan ini sesuai dengan pendapat Huda (2014) yang menyatakan bahwa model ini dapat meningkatkan kemampuan kognitif maupun fisik, memberikan pengalaman belajar yang menyenangkan karena adanya unsur permainan, dapat meningkatkan motivasi dan pemahaman dalam belajar. Faktor lainnya juga sebabkan karena adanya rancangan proses pembelajaran yang menarik karena dalam pembelajaran yang menggunakan model make a match ini terdapat adanya unsur permainan di dalam belajar. Hal inilah yang membuat peserta didik menjadi tertarik ketika mengikuti proses pembelajaran. Ketika peserta didik sudah tertarik dengan pembelajaran yang diberikan, maka materi yang diberikan dalam pembelajaran juga akan tersampaikan dengan baik.

Analisis pengaruh model pembelajaran kooperatif selanjutnya yakni pada kompetensi sikap. Kompetensi sikap merupakan salah satu aspek yang penting untuk ditanamkan dalam diri masing-masing peserta didik. Kompetensi sikap ini nantinya akan mencerminkan bagaimana perilaku dan pola pikir seseorang, serta sejauh mana kompetensi pengetahuan yang dimilikinya mampu diimplementasikannya dalam berperilaku di dalam lingkungan sosialnya.

Penelitian M8 membuktikan bahwa model pembelajaran kooperatif tipe make a match ini dapat meningkatkan sikap kerja sama, disiplin, dan sopan santun. Hal ini dapat dilihat dalam hasil persentase pengamatan sikap peserta didik yakni sebesar $90 \%$ peserta didik menunjukkan sikap bekerja sama yang baik dalam mencocokkan kartu yang diberikan. Sedangkan dalam hal disiplin sekitar $100 \%$ peserta didik disiplin dalam mencocokkan kartu, hanya saja dalam hal memberikan ulasan mengenai kecocokan kartu 
sedikit menurun yakni sekitar $85 \%$. Kemudian untuk sopan santun, peserta didik menunjukkan sikap saling menghargai dalam berdiskusi sehingga tercipta suasana yang lebih nyaman.

Hasil yang sama juga ditunjukkan dalam artikel hasil penelitian M9 dimana dalam artikel ini dijabarkan bahwa sebesar 95\% peserta didik menunjukkan sikap yang positif dalam hal sikap kerja sama, disiplin, tanggung jawab, sopan santun, dan saling menghargai.

Hal ini sejalan dengan hasil penelitian M10 yakni diperoleh bahwa sikap sosial peserta didik dalam pembelajaran IPA SMP meningkat. Hal ini dapat kita lihat bahwa hasil rata-rata kelas eksperimen yang diterapkan model pembelajaran make a match ini rata-rata nilai sikap atau keterampilan sosial peserta didik dikategorikan tinggi yakni sebesar 80,42, sedangkan kelas kontrolnya 76,33.

Dari beberapa hasil penelitian yang sudah penulis sajikan sebelumnya diketahui bahwa model pembelajaran kooperatif tipe make a match tidak hanya memberikan pengaruh positif terhadap sikap kerja sama saja, namun juga terlihat pada aspek kompetensi sikap lainnya yang harus dimiliki oleh peserta didik. Hal ini dapat dilihat dari hasil penelitian M9 dan M10 bahwa penerapan model pembelajaran ini membantu peserta didik untuk memupuk sikap disiplin, tanggung jawab, sopan santun, saling menghargai, dan beberapa aspek sikap lainnya. Munculnya peningkatan aspek sikap ini didukung oleh keunggulan yang ada dalam karakteristik model pembelajaran kooperatif tipe make a match ini yakni adanya penggunaan media berupa kartu soal dan juga kartu jawaban yang harus dipasangkan dalam proses pembelajaran. Sehingga dengan adanya media kartu yang harus dipasangkan dalam penerapan model pembelajaran make a match ini maka peserta didik merasa ada tuntutan yang harus dipenuhinya yaitu adanya tanggung jawab untuk mencari pasangan kartu,disiplin waktu untuk memasangkan kartu, dan sopan santun dalam aturan/etika dalam mencocokkan kartu ini.

Analisis artikel berikutnya menekankan pada aspek kompetensi keterampilan. Kompetensi ketampilan adalah kemampuan yang dimiliki untuk mengimplementasikan pengetahuan yang sudah dimiliki. Salah satunya dalam bentuk praktik, hal ini dapat kita lihat pada hasil penelitian M11 yang melaksanakan penilaian produk berupa pembuatan poster oleh peserta didik. Dalam penelitian ini, kompetensi keterampilan peserta didik diukur dengan lembar observasi. Berdasarkan hasil analisis observasi pada kompetensi keterampilan, maka diperoleh bahwa nilai rata-rata kelas yang menerapkan model pembelajaran kooperatif tipe make a match lebih tinggi dibandingkan kelas kontrolnya.

Penelitian M12 juga menunjukkan hasil yang sama yakni model pembelajaran make a match ini memberikan pengaruh yang positif terhadap kompetensi keterampilan peserta didik. Hal ini dapat kita lihat dari hasil rata-rata penilaian keterampilannya, dimana rata-rata kompetensi keterampilan kelas yang diterapkan model pembelajaran make a match lebih tinggi dibandingkan dengan kelas kontrolnya.

Dengan demikian, hasil penelitian ini menyatakan bahwa terjadi peningkatan pada penerapan model pembelajaran kooperatif tipe make a match berdasarkan kajian literatur yang sudah dilaksanakan. Dari beberapa kajian literatur ini peneliti tidak menemukan adanya artikel yang menyatakan kegagalan penerapan model ini di Indonesia.

\section{SIMPULAN}

Berdasarkan hasil kajian beberapa literature (systematic review) dalam beberapa artikel-artikel ilmiah yang telah diakses melalui SINTA, Google scholar dan beberapa situs-situs jurnal ilmiah lainnya, maka penulis memperoleh kesimpulan bahwa model pembelajaran kooperatif tipe make a match ini memberikan pengaruh yang positif terhadap kompetensi belajar (pengetahuan, sikap, dan keterampilan) peserta didik mulai dari tingkat SD, SMP, SMA, dan SMK. Dengan demikian, model pembelajaran 
kooperatif tipe make a match ini bisa menjadi pertimbangan oleh guru untuk membangkitkan kembali semangat belajar peserta didik sehingga kompetensi belajarnya juga akan meningkat terutama di zaman seperti sekarang ini.

\section{UCAPAN TERIMA KASIH}

Penulis mengucapkan terima kasih kepada Allah SWT. sehingga dengan ridho-Nya penulis bisa menyelesaikan artikel ini dengan baik. Penulis juga mengucapkan terima kasih kepada lbu Dra. Helendra, M.S., Bapak Dr. Syamsurizal, M.Biomed., dan Ibu Dr. Heffi Alberida, M.Si. yang telah banyak memberikan bimbingan, kritik, dan saran demi selesainya artikel ini. Lalu, penulis juga mengucapkan terima kasih kepada keluarga dan semua pihak yang sudah memberikan dukungan kepada penulis untuk bisa menyelesaikan artikel ini.

\section{RUJUKAN}

Apriyeni, dkk. (2016). Pengaruh Model Cooperatif Learning Tipe Make a Match dalam Pembelajaran IPA Terhadap Keterampilan Sosial dan Hasil Belajar Kognitif Siswa SMP. Pendidikan IImu Pengetahuan Alam Indonesia, 1-7.

Asma, Nur. (2012). Model Pembelajaran Kooperatif. Padang: UNP Press.

Depdiknas. (2003). Undang-undang RI No. 20 tahun 2003 tentang sistem pendidikan nasional

Fadilla, Medina, dkk. (2019). Pengaruh Penerapan Model Pembelajaran Kooperatif Tipe Make a Match Terhadap Kompetensi Belajar Peserta Didik di SMPN 1 Solok. Atrium Pendidikan Biologi, 96105.

Hamid, Nur. (2018). Pengaruh Model Pembelajaran Kooperatif Tipe Make a Match Terhadap Kreativitas, Motivasi, dan Hasil Belajar Biologi pada Materi Tumbuhan Lumut Kelas X SMA Negeri 2 Sarmi. Jurnal IImu Pendidikan Indonesia, 39-46.

Huda, Miftahul. (2014).Model-model Pengajaran dan Pembelajaran.Yogyakarta: Pustaka pelajar

Kayame, Martinus, dkk. (2014). Pengaruh Pembelajaran Kooperatif Tipe Make a Match dan Hasil Belajar Terhadap Motivasi Belajar Matematika Peserta Didik Kelas XI IPA SMA YPPGI Wamena Kabupaten Jaya Wijaya. Jurnal IImu Pendidikan Indonesia, 48-62.

Khoirunnisa, dkk. (2016). Efektivitas Model Make a Match Terhadap Hasil Belajar Siswa Materi Archaebacteria dan Eubacteria di SMA. Pendidikan dan Pembelajaran Untan, 1-11.

Nurdiani, dkk. (2019). Pengaruh Pemberian Sistem Point pada Model Pembelajaran Make a Match Terhadap Kompetensi Belajar IPA Peserta Didik Kelas VIII SMPN 21 Padang. Atrium Pendidikan Biologi, 50-60.

Nurhidayah, Rina Suryati, dkk. (2017). Penerapan Model Pembelajaran Kooperatif Tipe Make a Match untuk Meningkatkan Hasil Belajar Siswa pada Materi Keragaman Suku Bangsa dan Budaya. Pena IImiah, 2051-2060.

Paramita, Irma, dkk. (2012). Penggunaan Model Cooperatif Learning Type Make a Match Terhadap Hasil Belajar Sistem Gerak . Journal of Biology Education, 287-294.

Rusman. (2011). Model-model Pembelajaran Mengembangkan Profesionalisme Guru. Jakarta: Raja Grafindo Persada.

Sabrianto, dkk. (2013). Upaya Meningkatkan Hasil Belajar Fisika Melalui Penerapan Model Pembelajaran Kooperatif Make a Match pada Siswa Kelas X TKJ SMK Nasional Makassar. Pendidikan Fisika Unismuh, 244-251.

Sari, Debby Verama, dkk. (2018). Keefektifan Kartu Make a Match pada Materi Sistem Rangka Terhadap Hasil Belajar Siswa Kelas XI SMA. Berkala IImiah Pendidikan Biologi, 252-259.

Sirait, Makmur, dkk. (2013). Pengaruh Model Pembelajaran Kooperatif Tipe Make a Match Terhadap Hasil Belajar Siswa. Jurnal INPAFI, 252-259.

Sudjana, Nana. 2011. Dasar-dasar Proses Belajar Mengajar. Bandung: Sinar Baru Algensindo. 
BIODIK: Jurnal IImiah Pendidikan Biologi

Vol. 07, No. 04 (2021), Hal. 29 - 38

Weni, Rilda. (2017). Model Cooperative Learning Tipe Make a Match untuk Meningkatkan Hasil Belajar dan Aktivitas Peserta Didik. Jurnal Penelitian Pendidikan Indonesia, 42-50.

Yunus, S. R. (2018). Pengaruh Model Pembelajaran Kooperatif Tipe Make a Match terhadap Hasil Belajar Peserta Didik Kelas VII SMP Negeri Kahu (Materi Pokok Ekosistem). Jurnal IPA Terpadu, 68-77. 